Research Paper:

\title{
The Impact of an Android Application on Compliance With Iron Supplementations in Pregnant Women
}

\author{
Enny Susilawati $^{1^{*}}$ (D), Yuli Suryanti ${ }^{1}$ (D) Lia Artika Sari $^{1}$ (D), Herinawati ${ }^{1}$ (D), Ika Murtiyarini ${ }^{1}$ (D)
}

1. Department of Midwifery, Health Polytechnic of Jambi, Indonesia.

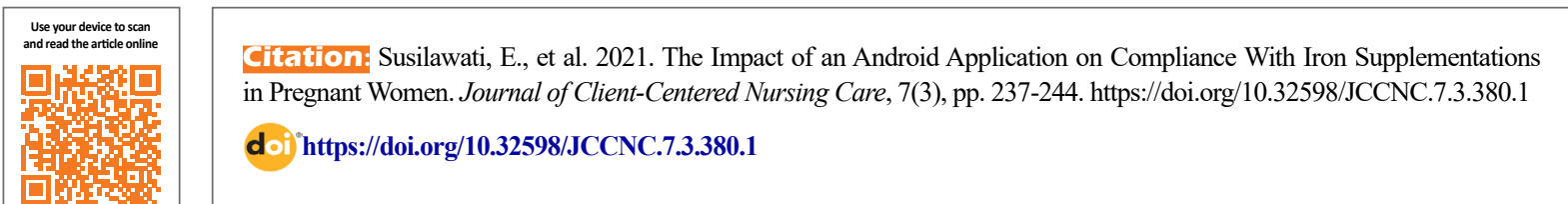

\section{(i) (\$)}

Article info:

Received: 27 May 2021

Accepted: 10 Jul 2021

Published: 01 Aug 2021
Keywords:

Hemoglobin, Third trimester, Pregnant women, Ferrous fumarate, Adherence

\begin{abstract}
A B S T RA C T
Background: Monitoring the adherence of pregnant women to taking iron supplements indicates controlling the appropriateness of taking a certain number of supplements. This increases the odds of effective iron absorption; a process that occurs by consuming at least 30 iron pills a month to prevent gestational anemia. This study aimed to determine the effects of monitoring pregnant women's compliance in taking up iron supplements through an Android application in Jambi City, Indonesia.
\end{abstract}

Methods: This was a quasi-experimental single group study with a pre-test-post-test design The study subjects included a convenient sample of women in their third trimester referring to 3 maternity Hospitals in Jambi City, Indonesia, in 2020. Initial data were obtained through Hemoglobin $(\mathrm{Hb})$ measurements before being given a monitoring application and subsequent $\mathrm{Hb}$ level checks after giving the application. The obtained data were analyzed by t-test and Mann-Whitney U test in SPSS 16. A significance level of 5\% was considered.

Results: The results obtained in the initial examination indicated that the minimum $\mathrm{Hb}$ level was equal to $7.3 \mathrm{~g} / \mathrm{dL}$ and the maximum level was measured as $11.2 \mathrm{~g} / \mathrm{dL}$. After the intervention, the $\mathrm{Hb}$ level increased to a minimum of $7.6 \mathrm{~g} / \mathrm{dL}$ and a maximum of $12.2 \mathrm{~g} / \mathrm{dL}$. The Mann-Whitney $\mathrm{U}$ test data suggested a significant difference in the degree of compliance of pregnant women with iron supplementation $(\mathrm{P}=0.010)$.

Conclusion: Monitoring through the Android application increased pregnant women's compliance with taking iron supplements and presented a linear impact on increasing their $\mathrm{Hb}$ level.

\footnotetext{
* Corresponding Author:

Enny Susilawati

Address: Department of Midwifery, Health Polytechnic of Jambi, Indonesia.

Tel: +62 (853) 15962322

E-mail: ennysusilawati.poltekkes@gmail.com
} 


\section{Highlights}

- Failure to take iron supplements during pregnancy increases the incidence of pregnancy anemia.

- Anemia in pregnant women brings consequences and complications, such as the high risk for miscarriage, bleeding, low birth weight, uterine atony, uterine inertia, and retained placenta.

- The purpose of the smartphone application is to monitor pregnant women's compliance with taking iron supplements to prevent anemia.

- The study findings indicated that using a smartphone application increases $\mathrm{Hb}$ levels by increasing the adherence of pregnant women to taking iron supplements.

\section{Plain Language Summary}

Monitoring hemoglobin levels is essential in pregnant women. This is because the lack of hemoglobin can negatively impact the health of the mother and fetus in the womb. Having a smartphone application to monitor the compliance of pregnant women with taking iron supplements is effective. It can be used as a reminder for the regular use of iron supplements; thus, reducing the incidence of anemia in pregnancy. According to the present study findings, using a smartphone application increases hemoglobin levels by improving the adherence of pregnant women to taking iron supplements.

\section{Introduction}

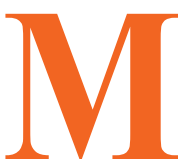

aternal Mortality Rate (MMR) is an indicator of community health (Sajedinejad et al. 2015). The World Health Organization (WHO) has reported the prevalence of MMR as 239 deaths for every 100000 live births in the Least Developed Countries (LDCs), compared to 124 deaths for every 100000 live births in Developed Countries (DC), in 2015. The difference in these ratios is 115 between regions, countries, different socio-economic strata, as well as rural and urban populations (World Health Organization 2018). Based on the Indonesian Demographic Health Survey (IDHS) in 2015, Maternal Mortality Rate (MMR) in Indonesia has been reported as 305/100000 live births (Badan Pusat Statistik 2017).

The cause of the high MMR in Indonesia is inseparable from the complications during pregnancy, childbirth, and puerperium. The causes of high MMR include bleeding (28\%), eclampsia (24\%), and infection (11\%). However, other indirect causes, such as nutritional problems leading to anemia in pregnancy (40\%), chronic energy deficiency (27\%), and consumption patterns below the minimum requirement (44.2\%) should also be considered (Kemenkes 2018). Approximately $48.9 \%$ of pregnant women in Indonesia experience anemia. Accordingly, it remains a community problem, because the proportion is higher than the primary health research results in 2013 , i.e., $37.1 \%$ (Kemenkes 2018).
In 2016, the local government published the results of a statistical study. According to this, the frequency of anemias in pregnant women equaled $1261(9.38 \%)$ mothers, and in 2017, it increased to 1338 (11.4\%). Therefore, all 20 Public Health Centers (PHC) in Jambi City were covered by the supply of 90 tablets of iron supplements with coverage of $>90 \%$ (Kota Jambi 2018).

According to Radkar and Parasuraman (2007), the anemia-induced maternal mortality rate is $19.7 \%$ of total MMR in India (2007). Approximately $15 \%-20 \%$ of maternal deaths are directly or indirectly due to anemia. Additionally, increased maternal morbidity is also associated with anemia. The main cause of anemia in pregnant women is an iron deficiency; however, pregnant women rarely develop iron deficiency anemia due to nutritional problems (Kautshar, Suriah \& Jafar 2013).

Pharmacological treatment for anemia is taking one iron supplement a day during pregnancy (Dahlan \& Ardhi, 2021). Anemia, in all countries, particularly the developing regions, is mainly caused by iron deficiency (Gedefaw et al. 2015; Noronha et al. 2012; Plante et al. 2011). Inadequate iron intake, high iron absorption during pregnancy, iron loss due to bleeding, and infectious diseases are considered as the leading causes of iron deficiency (Gedefaw et al. 2015).

The nationally developed Anemia Prevention Program provides iron supplements for pregnant women with at 
least 90 tablets during pregnancy (Agustina 2019). A study in Pageraji Village Cilongok, the District of Banyumas Regency, Indonesia, found a significant difference between pregnant women who were adherent to taking iron tablets (50.9\%), compared to non-adherent women $(49.1 \%)$, with a $50 \%$ anemia incidence. Therefore, compliance with consuming iron supplements significantly affects the incidence of anemia in pregnant women (Anasari \& Tri, 2012). Non-Compliance with taking iron supplements increases the risk of anemia during pregnancy fourfold (Wiradnyani , Khusun \& Achadi 2013).

Therefore, pregnant women need to become familiar with the benefits of regular consumption of iron supplements through an efficient monitoring system. In this study, an online Android system was used to monitor iron supplementation in pregnant women, with the expectation that this mechanism will increase mothers' adherence to iron supplementation. An overgrowing media that can easily and attractively present guidelines is an Android-based smartphone (Intan Trivena Maria Daeng, Mewengkang \& Kalesaran 2017). The capabilities of Android smartphones, including multimedia capabilities, high portability, and local data storage, can help healthcare workers by providing information about case management and decision support applications that impact improving service quality (Florez-Arango et al. 2011). This study aimed to determine the effects of monitoring pregnant women's compliance with taking up iron supplements through an Android application in Jambi City, Indonesia.

\section{Materials and Methods}

This was a quasi-experimental single group study with two $\mathrm{Hb}$ measurements before and after the intervention. Fifty mothers in their third trimester of pregnancy were conveniently recruited as the sample at the visit to $\mathrm{Ob}$ gyn Hospitals in Jambi City, Indonesia, in 2020. The inclusion criteria were being in the third trimester of pregnancy, to participate in the study and have an android cell phone.

Initially, an intervention called process (X) (i.e., using an Android application) was performed at the input $\left(\mathrm{O}_{1}\right)$ and after output (i.e., the determination of compliance), the result of treatment and test $\left(\mathrm{O}_{2}\right)$ (i.e., changes in $\mathrm{Hb}$ ) were compared. Accordingly, the necessary data were collected based on the results of $\mathrm{Hb}$ measurements before and after being given the Android application. The study participants' Hb levels were measured using Sahli's $\mathrm{Hb}$ method before and after the intervention. Adherence was monitored by a smartphone application; it was assessed by checking the number of consumed iron supplements for 30 days using observation sheets. If the number of iron tablets taken was $<30$, it was rated as $0=$ non-adherence; $\geq 30$ was rated as $1=$ adherent. To use the application, the respondents were requested to install it on their smartphones. Then, the research team explained how to work with it. To measure compliance, the explored mothers were requested to click on the program on a specific day and date after taking each iron supplement and continue the same measure for a full 30 days. Not clicking on the data on the app indicates that the respondent is not taking iron supplements. The Android app also has a standby operator to recapitulate the respondents' data. The respondents were reminded via WhatsApp at 3 Obgyn Hospitals in Jambi. A group of enumerators assisted research data collection. The data were analyzed by t-test and Mann-Whitney $U$ test in SPSS 16, at a significance level of 0.05 .

\section{Results}

The demographic characteristics of the study subjects are presented in Table 1. Based on Table 2, the distribution of the data was not normal; therefore, non-parametric tests were applied to analyze the collected data. Table 3 suggests that before monitoring compliance with the intake of iron supplements through the application, the minimum $\mathrm{Hb}$ of the respondents equaled $7.3 \mathrm{~g} / \mathrm{dL}$ and the maximum was measured as $11.2 \mathrm{~g} / \mathrm{dL}$. After using the application, $\mathrm{Hb}$ levels reached a minimum of $7.6 \mathrm{~g} /$ $\mathrm{db}$ and a maximum of $12.2 \mathrm{~g} / \mathrm{dL}$.

Table 4 demonstrates that most women (78\%) were adherent to taking iron supplementations. The relationship between monitoring the compliance of pregnant women with taking iron supplementations via an Android application with an increase in $\mathrm{Hb}$ is presented in Table 5 .

Table 5 reveals that the mean value equaled 30.06 , indicating that adherent women had more influence on the increase in $\mathrm{Hb}$ levels $(\mathrm{P}=0.010)$.

\section{Discussion}

Anemia is a condition of decreased red blood cells or $\mathrm{Hb}$ which results in a lack of oxygen-carrying capacity for the needs of vital organs in pregnant women and the fetus (Widness 2008). An indication for anemia is if the $\mathrm{Hb}$ concentration is $<10.5$ to $11.0 \mathrm{~g} / \mathrm{dL}$ (Lumbanraja et al. 2019). Supplementation with iron tablets is a valuable approach to treat anemia; using tablets containing $60 \mathrm{mg} /$ day can increase $\mathrm{Hb}$ levels. Iron supplementation has long been routinely given to pregnant women at PHC, 
Table 1. Frequency distribution of respondents' characteristics

\begin{tabular}{ccc}
\hline & Characteristics & No. (\%) \\
\hline Age $(\mathrm{y})$ & $20-29$ & $37(74.0)$ \\
& $30-40$ & $13(26.0)$ \\
\hline Education Level & High (> High School) & $14(28.0)$ \\
& Low (< High School) & $36(72.0)$ \\
Occupation & Housewives & $39(78.0)$ \\
& Civil servant & $4(8.0)$ \\
Parity & Entrepreneur & $7(14.0)$ \\
& Primiparous & $20(40.0)$ \\
\hline
\end{tabular}

and Health and Nutrition Integrated Service Center (Posyandu) in Indonesia (Shanti et al. 2017).

The Mann-Whitney $\mathrm{U}$ test provided a $\mathrm{P}=0.010$; thus, there existed differences in $\mathrm{Hb}$ levels before and after monitoring using a smartphone application, with changes in $\mathrm{Hb}$ levels from $11.2 \mathrm{~g} / \mathrm{dL}$ to a maximum of $12 \mathrm{~g} / \mathrm{dL}$. Monitoring the respondents' $\mathrm{Hb}$ levels significantly impacted pregnant women's compliance in taking iron supplements.

The obtained results were in line with those of several research that illustrated the significant impact of smartphone-based applications on the quality of antenatal care. MnNabb et al. (2015) argued that "the change Antenatal Care (ANC) application" can increase the ANC service quality score, especially the health education domain, which had the highest quality score increase from 5.45 at the beginning to 8.67 points $(\mathrm{P}<0.001)$. Likewise, client satisfaction increased from $75 \%$ to $83 \%(\mathrm{P}<0.05)$ (McNabb et al. 2015).

Our results were also in line with a study at Al-Yamamah Hospital, Riyadh, Saudi Arabia. They found that the non-adherence of pregnant women to taking iron supplements was significantly associated with an enhanced anemia rate from $29.6 \%$ in the first trimester to $34 \%$ in the third trimester (Habib et al. 2009) since usually no basic changes occur in the composition of the diet. A retrospective cohort study was carried out in Al-Yamamah Hospital, Riyadh, Saudi Arabia, to compare the outcome of hemoglobin levels in 308 pregnant women near term with compliance to iron supplementation during the preceding pregnancy stages. Data were collected using an interview-based questionnaire for assessment of supplementation compliance and the women were divided into three categories: strictly compliant; partially compliant; and non-compliant. Hemoglobin levels were extracted from the medical records for the first antenatal visit (before 13 weeks' gestation. It was turned out that smartphone-based application is effective on pregnan women's compliance with taking iron tablets (Rukmaini, Sapurti \& Aisyiah 2018).

Similar to our results, there was a mean adherence to the asthma treatment of $82 \%$ in patients receiving daily SMS reminders, compared to $70 \%$ in the group that received no reminders (Strandbygaard, Thomsen \& Backer 2010). In another study, text messages improved adherence to immunosuppressant treatment in the liver transplant recipients as measured by blood medicine concen-

Table 2. The results of data normality test related to the effect of compliance through Android application on Hb increase

\begin{tabular}{ccccccc}
\hline & \multicolumn{3}{c}{ Kolmogorov-Spirnov } & \multicolumn{3}{c}{ Shapiro-Wilks } \\
\cline { 2 - 8 } Outcome Measure & Statistic & df & Sig. & Statistic & df & Sig. \\
\hline $\mathrm{Hb}$ (Pre-test) & 0.192 & 50 & 0.000 & 0.926 & 50 & 0.004 \\
$\mathrm{Hb}$ (Post-test) & 0.161 & 50 & 0.002 & 0.897 & 50 & 0.000 \\
\hline
\end{tabular}


Table 3. Hb levels of the examined pregnant women before and after iron supplements monitoring through the Android application ( $N=50)$

\begin{tabular}{ccccc}
\hline Hb Measurement & N & Min. & Max. & Mean $\pm S D$ \\
\hline Before being monitored & 50 & 7.3 & 11.2 & $9.640 \pm 0.928$ \\
After being monitored & 50 & 7.6 & 12.2 & $10.376 \pm 0.920$ \\
\hline
\end{tabular}

trations (Miloh et al. 2009). Studies involving patients with Human Immunodeficiency Virus (HIV) revealed the following information: significantly higher adherence in patients who received daily mobile reminders, compared to patients alerted by pagers; $>95 \%$ adherence in patients receiving SMS reminders, compared to the group that received no reminders (Pop-Eleches et al. 2011).

Based on brief interviews between the researchers in a study and several respondents, pregnant women had received iron supplements during antenatal care; however, they had not taken them regularly and often forgot to take the blood-boosters. Therefore, it is necessary to have an application to monitor the activities of pregnant women in taking vitamins or supplements (Wang et al. 2019).

One strategy to improve patient behavior in treatment is to provide controlled treatment services to patients at home based on mobile technology (Vervloet et al. 2012). A subject is said to be obedient if the provided medicine is used up or reduced according to the predetermined schedule and is willing to follow the physician's or other healthcare staff's recommendations. The individual is said to be disobedient if they neglect obligations to perform the recommendations of physicians/healthcare workers (Putri et al. 2020).
Formally, a tool or job guide is defined as an external device that provides direct knowledge and information to help, direct, guide, and improve the performance of individuals in their tasks (Florez-Arango et al. 2011).

At the end of the intervention, the explored non-compliant women stated that in addition to forgetting, their non-compliance was also because of complications, such as nausea, constipation, or difficulty in defecating; consequently, they discontinued taking iron supplementations. The present study explicated the apparent efficacy of using an android-based application as a reminder with actual results. This is because the impact of increasing maternal compliance in taking iron supplements is evident from the lack of anemia in pregnant women and an increase in their Hb levels.

This smartphone application was not equipped with a menu to upload documents or jpg files. Therefore, the limitation of this study was the absence of complete documentary evidence in the application that presents if the respondent is taking iron supplements. For example, by sending photo documentation through this application when taking iron supplements.

Table 4. Describing the status of the examined women concerning compliance with taking iron supplementation

\begin{tabular}{|c|c|c|}
\hline No & Compliance & No. (\%) \\
\hline 1 & No & $11(22.0)$ \\
\hline 2 & Yes & $39(78.0)$ \\
\hline \multicolumn{2}{|c|}{ Total } & $50(100)$ \\
\hline
\end{tabular}

Table 5. Differences in the mean adherence values of respondents in taking iron supplementations with increased $\mathrm{Hb}$ after monitoring $(\mathrm{N}=50)$

\begin{tabular}{ccc}
\hline Adherence & Mean \pm SD & P \\
\hline Adherent & $30.06 \pm 3.679$ & 0.010 \\
Not adherent & $9.32 \pm 0.911$ & \\
\hline
\end{tabular}

*Mann-Whitney U test. 


\section{Conclusion}

The current research data indicated that monitoring the consumption of iron supplements using an Android application improves pregnant women's compliance with taking iron supplements and leads to increasing their $\mathrm{Hb}$ levels. Using such an application is recommended for improving pregnant women's compliance with iron supplementations by healthcare workers and midwives.

\section{Ethical Considerations}

\section{Compliance with ethical guidelines}

The study was approved by the Health Research Ethics Committee of Health Polytechnic of Jambi (Reference number LB.02.06/2/136/2020). The subjects sought their signed informed consent for participation in the study.

\section{Funding}

This research did not receive any grant from funding agencies in the public, commercial, or non-profit sectors.

\section{Authors' contributions}

All authors equally contributed to preparing this article.

\section{Conflict of interest}

The authors declared no conflict of interest.

\section{Acknowledgments}

We express our gratitude to the director of Health Polytechnic Jambi for its support for the implementation of this research

\section{References}

Agustina, W., 2019. [Comparison of hemoglobin levels in pregnant moms who comsume iron tablets with and without vitamin c in the puskesmas working area langsa lama 2019 (Indonesian)]. Jurnal Nasional Ilmu Kesehatan, 2(2), pp.76-87. https:/ / journal.unhas.ac.id/index.php/jnik/article/view/7080

Anasari, T., 2012. [Compliance relationship of pregnant mothers consuming fe . tablets with the event of anemia in pageraji village, sub-district cilongok, banyumas regency (Indonesian)]. Bidan Prada: Jurnal Publikasi Kebidanan STIKes YLPP Purwokerto, 3(2), pp. 41-53. https://d1wqtxts1xzle7.cloudfront. net/58604263/59-113-1-SM-with-cover-page-v2.pdf?Expires $=1631593197 \&$ Signature $=$
Badan Pusat Statistik. [Indonesian Demographic and Health Survey Report, 2017 (Indonesian)]. Statistics Indonesia. [Internet]. 2021. https://www.bps.go.id/

Dahlan, F. M., \& Ardhi, Q., 2021. The effect of fe tablet and date palm on improving hemoglobin level among pregnant women in the third semester. Journal of Midwifery, 5(1), pp. 31-8. [DOI:10.25077/jom.5.2.32-38.2020]

Kota Jambi, D. K. 2018. [Profil Kesehatan Kota Jambi (Indonesian)]. [Internet]. https:/ / e-renggar.kemkes.go.id/file2018/eperformance/1-109002-2tahunan-619.pdf

Florez-Arango, J. F., et al. 2011. Performance factors of mobile rich media job aids for community health workers. Journal of the American Medical Informatics Association, 18(2), pp. 131-7. [DOI:10.1136/jamia.2010.010025]

Gedefaw, L., et al. 2015. Anemia and associated factors among pregnant women attending antenatal care clinic in Walayita Sodo town, Southern Ethiopia. Ethiopian Journal of Health Sciences, 25(2), pp. 155-64. [DOI:10.4314/ejhs.v25i2.8]

Habib, F., et al. 2009. Compliance to iron supplementation during pregnancy. Journal of Obstetrics and Gynaecology, 29(6), pp. 487-92. [DOI:10.1080/01443610902984961]

Daeng, ITM., Mewengkang, N. N. \& Kalesaran, E. R., 2017. [The use of smartphones in supporting lecture activities by fispol unsrat manado students by (Indonesian)]. E-Journal Acta Diurna, 6(1), pp. 1-15. https://ejournal.unsrat.ac.id/index.php/ actadiurnakomunikasi/article/view/15482

Kautshar, N., Suriah, J. N. \& Jafar, N., 2013. [The obedience of pregnant women in consuming iron substance tablets (fe) in bara-baraya health center of makassar city in 2013 ((Indonesian)]. Jurnal Gizi Dan Pangan, 2(1), pp. 12-21. http://pasca.unhas. ac.id/jurnal/files/2838ec295ddbb8912d283bac2b79fa48.pdf

Kemenkes, R. I. 2018. Hasil utama RISKESDAS 2018; Kementerian Kesehatan Badan Penelitian dan Pengembangan Kesehatan [Internet]. https://kesmas.kemkes.go.id/assets/upload/ dir_519d41d8cd98f00/files/Hasil-riskesdas-2018_1274.pdf

Lester, R. T., et al. 2010. Effects of a mobile phone short message service on antiretroviral treatment adherence in Kenya (WelTel Kenya1): A randomised trial. The Lancet, 376(9755), pp. 1838-45. [DOI:10.1016/S0140-6736(10)61997-6]

Lumbanraja, S. N., et al. 2019. The correlation between hemoglobin concentration during pregnancy with the maternal and neonatal outcome. Open Access Macedonian Journal of Medical Sciences, 7(4), pp. 594-8. [DOI:10.3889/oamjms.2019.150]

McNabb, M., et al. 2015. Assessment of the quality of antenatal care services provided by health workers using a mobile phone decision support application in Northern Nigeria: A pre/post-intervention study. PLOS One, 10(5), p. e0123940. [DOI:10.1371/journal.pone.0123940]

Miloh, T., et al. 2009. Improved adherence and outcomes for pediatric liver transplant recipients by using text messaging Pediatrics, 124(5), pp. e844-50. [DOI:10.1542/peds.2009-0415]

Noronha, J. A., et al. 2012. Anemia in pregnancy-consequences and challenges: A review of literature. Journal of South Asian Federation of Obstetrics and Gynecology, 4(1), pp. 64-70. [DOI:10.5005/jp-journals-10006-1177]

Plante, C., et al. 2011. Prevalence of anemia among Inuit women in Nunavik, Canada. International Journal of Circumpolar Health, 70(2), pp. 154-65. [DOI:10.3402/ijch.v70i2.17811]

Pop-Eleches, C., et al. 2011. Mobile phone technologies improve adherence to antiretroviral treatment in a resource-limited set- 
ting: A randomized controlled trial of text message reminders. AIDS (London, England), 25(6), pp. 825-34. [DOI:10.1097/ QAD.0b013e32834380c1]

Putri, S., et al. 2020. The role of medication observer and compliance in medication of pulmonary tuberculosis patient. Jurnal Kesehatan Prima, 14(1), pp. 1-8. [DOI:10.32807/jkp.v14i1.248]

Radkar, A. \& Parasuraman, S., 2007. Maternal deaths in India: An exploration. Economic and Political Weekly, 42(31), pp. 325963. https://www.researchgate.net/publication/262127625 Maternal_Deaths_in_India_An_Exploration

Rukmaini, R., Sapurti, M. E. \& Aisyiah, A., 2018. The effect of mother perception and family support program on improving anemia related knowledge among pregnant women. Paper Presented at the $3^{\text {rd }}$ International Nursing Conference Community Health Empoverment, Jember, Indonesia, 4-5 November 2017. https://www.researchgate.net/ publication/325360247_THE_EFFECT_OF_MOTHER_PERCEPTION_AND_FAMILY_SUPPORT_PROGRAM_ON IMPROVING_ANEMIA_RELATED_KNOWLEDGE_ AMONG_PREGNANT_WOMEN

Sajedinejad, S., et al. 2015. Maternal mortality: A cross-sectional study in global health. Globalization and Health, 11(1), pp. 1-13. [DOI:10.1186/s12992-015-0087-y]

Shanti, K. M., et al. 2017. [Evaluation of the program for giving blood supplementation tablets as a preventive and curative effort for anemia in pregnant women at the kraton public health center, Yogyakarta City (Indonesian)]. Berita Kedokteran Masyarakat, 33(5). https://journal.ugm.ac.id/bkm/article/ view/37448

Strandbygaard, U., Thomsen, S. F. \& Backer, V. 2010. A daily SMS reminder increases adherence to asthma treatment: A three-month follow-up study. Respiratory Medicine, 104(2), pp. 166-71. [DOI:10.1016/j.rmed.2009.10.003]

Vervloet, M., et al. 2012. SMS reminders improve adherence to oral medication in type 2 diabetes patients who are real time electronically monitored. International Journal of Medical Informatics, 81(9), pp. 594-604. [DOI:10.1016/j.ijmedinf.2012.05.005]

Wang, N., et al. 2019. Understanding the use of smartphone apps for health information among pregnant Chinese women: Mixed methods study. JMIR Mhealth Uhealth, 7(6), p. e12631. [DOI:10.2196/12631]

Widness, J. A., 2008. Pathophysiology of anemia during the neonatal period, including anemia of prematurity. Neoreviews, 9(11), pp. e520-5. [DOI:10.1542/neo.9-11-e520]

Wiradnyani, L. A. A., Khusun, H. \& Achadi, E. L., 2013. Faktorfaktor yang berhubungan dengan kepatuhan ibu mengonsumsi tablet besi-folat selama kehamilan. Jurnal Gizi Dan Pangan, 8(1), pp. 63-70. [DOI:10.25182/jgp.2013.8.1.63-70]

World Health Organization (WHO)., 2018. Maternal mortality [Internet]. Cited 28 July 2021, https://www.who.int/newsroom/fact-sheets/detail/maternal-mortality 
This Page Intentionally Left Blank 